\title{
Cholangiocarcinoma with Sepsis Associated with Percutaneous Transhepatic Biliary Drainage (PTBD)
}

\author{
Muhammad Vitanata Arfijanto*, Bayu Abhiyoga** \\ ${ }^{*}$ Division of Tropical \& Infectious Disease, Department of Internal Medicine \\ Faculty of Medicine, Universitas Airlangga/Dr. Soetomo General Hospital, Surabaya \\ ${ }^{* *}$ Department of Internal Medicine, Faculty of Medicine \\ Universitas Airlangga/Dr. Soetomo General Hospital, Surabaya
}

\begin{abstract}
Corresponding author:
$M$ Vitanata Arfijanto. Division of Tropical Infectious Disease, Faculty of medicine, Universitas Airlangga/ Dr. Soetomo General Hospital. Jl. Mayjend Prof Dr. Moestopo No.6-8 Surabaya Indonesia. Phone: +62-31-5501617; facsimile:+62-31-5018434.E-mail:drvitanata@gmail.com.
\end{abstract}

\begin{abstract}
Percutaneous transhepatic biliary drainage (PTBD) can be an alternative palliative treatment in resectable cholangiocarcinoma. One of the most common complications of PTBD is infection, with a prevalence of $3.6-$ $67.4 \%$ in patients undergoing PTBD procedure, with mortality rate of 0.05-7\%. We report a case of a 46-year old male with a history of fever 14 days after undergoing PTBD procedure. Physical examination revealed tachycardia, tachypnea, febris, jaundice, and decreased urine output. Laboratory results revealed hypochromicmicrocytic anemia, leukocytosis, decreased renal function, elevated liver enzymes, obstructive icterus, hypoalbuminemia, and hyperkalemia. Blood and gall culture revealed a growth of Eschericia coli. The patient was given fluid resuscitation and antibiotic suitable to microbial sensitivity test, and treatment of acute kidney injury and hyperkalemia, including hemodialysis. The patient's general condition improved after ten days of care, and was discharged on the twentieth day. Cholangitis is one of the most infectious complications following PTBD procedure. The prevalence of sepsis in biliary drainage procedures was reported $2.5-2.7 \%$, with enteral bacteria gram-negative bacilli being the most common pathogen found in blood and bile. The administration of prophylactic antibiotics was not proven to decrease prevalence of infection. Bacterial translocation via portal vein due to loss of mucosal integrity in the intestines may contribute to bacteremia following PTBD procedure.
\end{abstract}

Keywords: Cholangiocarcinoma, percutaneous transhepatic biliary drainage (PTBD), sepsis

\begin{abstract}
ABSTRAK
Percutaneous transhepatic biliary drainage (PTBD) dapat menjadi alternatif terapi paliatif pada pasien cholangiocarcinoma yang unresectable. Komplikasi tindakan PTBD yang umum yaitu infeksi dan perdarahan. Komplikasi infeksi terjadi pada 3,6-67,4\% pasien yang menjalani prosedur PTBD, dengan angka mortalitas 0,057\%. Kami melaporkan kasus seorang laki-laki 46 tahun dengan riwayat demam 14 hari setelah prosedur PTBD. Pemeriksaan fisik didapatkan takikardia, takipnea, febris, icterus, dan penurunan produksi urin. Pemeriksaan laboratorium didapatkan anemia hipokrom mikrositer, leukositosis, penurunan fungsi ginjal, peningkatan enzim hati, icterus obstruktif, hipoalbumin, dan hyperkalemia. Kultur darah dan cairan empedu menghasilkan pertumbuhan kuman Eschericia coli. Pasien diberikan resusitasi cairan, pemberian antibiotik sesuai hasil kultur, dan penanganan penyakit ginjal akut dan hiperkalemia, termasuk satu kali tindakan hemodialisis. Kondisi pasien
\end{abstract}


membaik setelah 10 hari perawatan, dan pasien dipulangkan setelah 20 hari perawatan. Cholangitis merupakan komplikasi infeksi yang paling umum ditemukan pada prosedur PTBD. Prevalensi sepsis pada prosedur drainase bilier dilaporkan berkisar angka 2,5-27\%. Pemberian antibiotik profilaksis tidak terbukti mengurangi kejadian infeksi pasca tindakan PTBD. Bakteri enterik basil gram-negatif merupakan organisme paling umum yang dapat ditemukan di cairan empedu dan darah. Translokasi bakteri melalui vena porta akibat hilangnya integritas mukosa usus dan perubahan mikroflora usus dapat berkontribusi terhadap bakteremia pasca tindakan PTBD.

Kata kunci: Cholangiocarcinoma, percutaneous transhepatic biliary drainage (PTBD), sepsis

\section{INTRODUCTION}

Sepsis is generally understood to be a clinical syndrome caused by infection that may have profound adverse physiologic consequences. Although its precise incidence is unknown, sepsis is believed to be a leading cause of critical illness and hospital mortality, accounting for more than one-third of all deaths in U.S. hospitals. ${ }^{1}$ For patients with sepsis, early identification and rapid intervention are crucial to the restoration of tissue perfusion.

Sepsis is a major cause of mortality among critically ill patients with malignancy. Between 270,000 and 380,000 people died of this disease annually. Patients with malignancy are nearly ten times more likely to develop sepsis than the general population, and cancer represents the most common co-morbidity in septic patients. ${ }^{2}$ The presence of pre-existing malignancy in murine hosts results in increased immune dysregulation and risk of mortality following a septic insult, with ICU and hospital mortality rates were $42 \%$ and $56 \%$, respectively. ${ }^{3}$

The most crucial aspect in the management of patients with sepsis is the concept that sepsis is a medical emergency. As with acute myocardial infarction and stroke, early identification and appropriate immediate management in the initial hours after development of sepsis improves outcomes For patients with sepsis, early identification and rapid intervention are crucial to the restoration of tissue perfusion. This case report focuses on a cholangiocarcinoma patient with sepsis related to infected percutaneous transhepatic biliary drainage (PTBD).

\section{CASE ILLUSTRATION}

A male patient, 46 years old, Javanese, lives at Surabaya, working as an employee, arrived to the Emergency Room in Dr. Soetomo General Hospital with chief complaint of fever since 2 weeks before admission, accompanied with general weakness. The patient also had nausea and vomiting consisting of remnant of latest meal, no history of coffee groundslike vomit, since 1 week before admission. Decreased urinary production since the last three days, with total volume less than $150 \mathrm{~mL}$. The patient has a history of hepatitis B since the last 13 years, and has been taking lamivudine $100 \mathrm{mg}$ daily for three months. The patient also has a history of cholangiocarcinoma, which was diagnosed 3 months prior, and lately underwent a percutaneous transhepatic biliary drainage (PTBD) procedure three weeks prior. He was administered broad-spectrum antibiotic 1 gram of cefotaxime three times a day for three days; one day before, during procedure, and one day after the procedure, and was discharged two days after. He also had yellow discoloration in his eyes and skin since three months before admission, which improved after PTBD procedure, but reverted to the worsened state since the last four days.

He had general weakness, with blood pressure of $96 / 63 \mathrm{mmHg}$, heart rate $108 \mathrm{bpm}$, respiratory rate 22 times per minute, and axillar temperature of $38.4^{\circ} \mathrm{C}$. Anemic conjunctiva, icteric sclera, and bile drainage in the middle right quadrant of the abdomen, with two drain bags each retaining $150 \mathrm{~mL}$ of bile fluid, pale and yellowish extremities, and urine production of $30 \mathrm{~mL}$ for the last 24 hours. Electrocardiography showed a sinus tachycardia $118 \mathrm{x} / \mathrm{m}$ Laboratory results are hemoglobin (Hb) $7.1 \mathrm{~g} / \mathrm{dL}$, hematocrit (HCT) $26.9 \%$, white blood cell (WBC) count $57.940 / \mathrm{mm}^{3}$, neutrophil count $93 \%$, platelet (plt) count $346.000 / \mathrm{mm}^{3}$. Blood sugar level 82 $\mathrm{mg} / \mathrm{dL}$, aspartate aminotransferase (AST) $130 \mathrm{U} / \mathrm{L}$; alanine aminotransferase (ALT) $76 \mathrm{U} / \mathrm{L}$; direct bilirubin level $13,49 \mathrm{mg} / \mathrm{dL}$, total bilirubin $19.17 \mathrm{mg} / \mathrm{dL}$; blood urea nitrogen (BUN) $117 \mathrm{mg} / \mathrm{dL}$; serum creatinine (SC) $14,16 \mathrm{mg} / \mathrm{dL}$; albumin $2.79 \mathrm{mg} / \mathrm{dL}$; sodium level $145 \mathrm{mEq} / \mathrm{L}$; potassium level $6,6 \mathrm{mEq} / \mathrm{L}$; chloride level $108 \mathrm{mEq} / \mathrm{L}$; lactate dehydrogenase (LDH) of $443 \mathrm{mg} /$ dL; PPT 20,7 (control 11,3), APTT 40,8 (control 24,3). HbsAg yielded reactive result, with detected HBVDNA $<29$ IU/L as of January 2017. Blood gas results 
pH 7.38; pCO2 30; pO2 95; $\mathrm{HCO} 3$ 17,7; BE-7,4; SO2 $96 \%$. Chest X-Ray showed no pulmonary metastatic processes, while abdominal magnetic resonance imaging (MRI) showed a solid mass with partially demarcated borders, the size of $5.6 \times 7.4 \times 4 \mathrm{cms}$ on common hepatic duct bifurcation, with slight contrast enhancement, that causes obstruction and dilation of right and left intrahepatic bile duct (IHBD), which is appropriate to the image of cholangiocarcinoma. Urologic ultrasound showed no abnormalities to the kidneys and urinary tract. The patient was assessed with cholangiocarcinoma on PTBD, sepsis related to PTBD, multiple organ dysfunction syndrome (MODS) manifested in hyperbilirubinemia and acute kidney injury (AKI) with hyperkalemia, anemia, and hypoalbuminemia.

The diagnostic planning comprised of taking blood and bile culture with antimicrobial sensitivity tests, and abdominal ultrasound to evaluate the placement of PTBD catheter. The patient received a central venous catheter to measure the central venous pressure. He was planned to receive high calorie, moderate protein, low potassium diet. He was then given fluid resuscitation of normal saline $1500 \mathrm{~mL}$ in three hours, proceeded by $1000 \mathrm{~mL}$ of normal saline in 24 hours. The blood and bile sample was taken before administering antibiotics. A combination of broad- spectrum antibiotics was administered intravenously, consisting of ceftriaxone 1 gram per 12 hours and levofloxacin $750 \mathrm{mg}$ per 48 hours, adjusted for renal impairment. The patient also received ranitidine intravenously $50 \mathrm{mg}$ twice daily, metoclopramide $10 \mathrm{mg}$ intravenously three times per day, and blood transfusion of packed red cells one bag per day, with the target hemoglobin of $8 \mathrm{~g} /$ dL. Hyperkalemia was corrected with $25 \mathrm{~mL}$ of $40 \%$ dextrose and two units of rapid-acting insulin, repeated each hour for two more times. Calcium gluconate $10 \mathrm{~mL}$ bolus was administered to prevent cardiac complication of hyperkalemia. The patient also received $500 \mathrm{mg}$ of paracetamol combined with $200 \mathrm{mg}$ of n-acetylcysteine three times a day, and $60 \mathrm{~mL}$ of lactulose syrup three times a day. The post-corrected potassium is 5.3 $\mathrm{mEq} / \mathrm{L}$. The patient's urine output did not improve after fluid administration.

The consultant nephrologist advised conservative management, and preparation of hemodialysis should it failed. We also consulted with a gastrohepatologist and was suggested palliative treatment and to treat the infection. A discussion with an interventional radiologist resulted in planning for evaluation of PTBD positioning by ultrasonography.
In the second day of treatment, the patient still had fever and loss of appetite, vomiting one time throughout the day. General weakness still present, blood pressure $120 / 70 \mathrm{mmHg}$, radial pulse $92 \mathrm{x} /$ minute, respiratory rate $20 \mathrm{x} /$ minute, axillar temperature $37.3^{\circ} \mathrm{C}, \mathrm{SaO} 2$ $98 \%$ with room air, urine output $20 \mathrm{~mL}$ per 24 hours, drainage output $300 \mathrm{~mL}$ per 24 hours, central venous pressure $11 \mathrm{cmH} 2 \mathrm{O}$. Evaluation of laboratory results

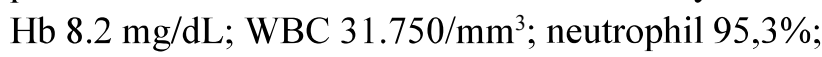
plt $256.000 / \mathrm{mm}^{3}$; blood sugar $85 \mathrm{mg} / \mathrm{dL}$; post-prandial blood sugar $99 \mathrm{mg} / \mathrm{dL}$; BUN $144 \mathrm{mg} / \mathrm{dL}$; SK 13,7 $\mathrm{mg} / \mathrm{dL}$; Ca $8,3 \mathrm{mEq} / \mathrm{L} ; \mathrm{P} 5,1 \mathrm{mEq} / \mathrm{L} ; \mathrm{Na} 142 \mathrm{mEq} / \mathrm{L}$; $\mathrm{K} 6,6 \mathrm{mEq} / \mathrm{L} ; \mathrm{Cl} 92 \mathrm{mEq} / \mathrm{L}$. Urine output $40 \mathrm{mLs}$ per 24 hours, bile production $250 \mathrm{mLs}$ per 24 hours. Fluid administration of normal saline $1000 \mathrm{mLs}$ per 24 hours, correction of hyperkalemia with $25 \mathrm{mLs}$ of $40 \%$ dextrose and two units of rapid-acting insulin, repeated each hour for two more times. The potassium level after correction is $5.4 \mathrm{mEq} / \mathrm{L}$.

In the third day of treatment, the patient still complained of general weakness and vomiting, despite improvement of fever. Blood pressure $110 / 70 \mathrm{mmHg}$, radial pulse $104 \mathrm{x} /$ minute, respiratory rate $20 \mathrm{x} /$ minute, axillar temperature $37.3^{\circ} \mathrm{C}$, central venous pressure $12 \mathrm{cmH}_{2} \mathrm{O}$. The evaluation of laboratory results post hyperkalemia correction $\mathrm{Na} 140 \mathrm{mEq} / \mathrm{L} ; \mathrm{K} 7,1$ $\mathrm{mEq} / \mathrm{L} ; \mathrm{Cl} 88 \mathrm{mEq} / \mathrm{L}$. A nephrologist was consulted and advised hemodialysis indicated by refractory hyperkalemia. Hemodialysis was performed with duration of 2.5 hours, QB 125-250 mLs, QD $500 \mathrm{mLs}$, ultrafiltration appropriate with fluid input during the procedure, heparin free, and one bag of red blood cells transfusion during the procedure.

In the fourth day of treatment, post dialysis, the patient still had vomiting and general weakness, although fever had improved considerably. Blood pressure $120 / 80 \mathrm{mmHg}$, radial pulse $98 \mathrm{x} /$ minute, axillar temperature $36,8^{\prime} \mathrm{C}, \mathrm{Hb} 8,9 \mathrm{~g} / \mathrm{dL}$; WBC $29.200 / \mathrm{mm}^{3}$; neutrophil $91 \%$; platelets $312.000 / \mathrm{mm}^{3}$; BUN $98 \mathrm{mg} /$ $\mathrm{dL}$; SK 11,4 mg/dL; sodium $141 \mathrm{mEq} / \mathrm{L}$; potassium 5,5 $\mathrm{mEq} / \mathrm{L}$; direct bilirubin $16,3 \mathrm{mg} / \mathrm{dL}$; total bilirubin 19,9 mg/dL, AST 144 IU/L, ALT 64 IU/L. Fluid input 1450 cc/24 hours; output $470 \mathrm{cc} / 24$ hours. Central venous pressure $9 \mathrm{cmH} 2 \mathrm{O}$. Blood culture resulted in gramnegative bacilli, sensitive to meropenem. Antibiotics was promptly switched to meropenem 1 gram per 12 hours administered intravenously, $\mathrm{NaCl} 0,9 \% 1000$ $\mathrm{mL}$ per 24 hours and aminofluid $500 \mathrm{ml}$ per 24 hours. Kalium resin exchange three times daily peroral. Evaluation of the PTBD showed no obstruction, and it was advised to replace the bag weekly, replace the 
dressing every three days, and ultrasound evaluation if the bile production is less than $200 \mathrm{~mL}$. The central venous pressure after fluid administration is $10 \mathrm{cmH} 20$.

In the seventh day of admission, nausea and vomiting improved. Vital signs are normal, drainage output $350 \mathrm{mls}$ per 24 hours, urine output $500 \mathrm{~mL} / 24$ hours. $\mathrm{Hb} 8,2 \mathrm{~g} / \mathrm{dL}$; WBC $24.150 / \mathrm{mm}^{3}$; neutrophil $90,3 \%$; platelets $251,000 / \mathrm{mm}^{3}$; BUN $80 \mathrm{mg} / \mathrm{dL}$; SK $9.8 \mathrm{mg} / \mathrm{dL} ; \mathrm{Na} 141 \mathrm{mEq} / \mathrm{L} ; \mathrm{K} 5,5 \mathrm{mEq} / \mathrm{L} ; \mathrm{Cl} 88 \mathrm{mEq} / \mathrm{L}$. The blood and bile culture was identified as Eschericia coli. He was given kalium exchange resin three times daily, with other treatment unchanged.

In the tenth day of treatment, the patient still had nausea but no vomiting and fever. Vital signs are normal, drainage output $350 \mathrm{mls} / 24$ hours, and improved urine output of $1500 \mathrm{mls} / 24$ hours. An abdominal ultrasound was performed, resulted in cholecystitis and suspected bilateral parenchymal kidney disease. $\mathrm{Hb} 8,6 \mathrm{~g} /$ dL; WBC $16.130 / \mathrm{mm}^{3}$; neutrophiles $84 \%$; platelets 238.000/. $\mathrm{mm}^{3}$; Na $133 \mathrm{mEq} / \mathrm{L} ; \mathrm{K} 5,1 \mathrm{mEq} / \mathrm{L}$; Cl 93 $\mathrm{mEq} / \mathrm{L} ; \mathrm{BUN} 72 \mathrm{mg} / \mathrm{dL}$; creatinine $8.7 \mathrm{mg} / \mathrm{dL}$; albumin $2,9 \mathrm{mg} / \mathrm{dL}$; direct bilirubin $9,0 \mathrm{mg} / \mathrm{dL}$; total bilirubin $13 \mathrm{mg} / \mathrm{dL}$. He was given intravenous fluid, $500 \mathrm{mls}$ of normal saline, $500 \mathrm{~mL}$ of dextrose $5 \%$, and $500 \mathrm{mls}$ of kalbamin. Fluid intake $500-1000 \mathrm{~mL} / 24$ hours. Other treatment continued.

In the fourteenth day of treatment, the patient was able to consume small amount of food without vomiting, vital signs normal, icterus was slightly improved, urine output $4200 \mathrm{mls}$ per 24 hours, drainage output $400 \mathrm{cc} / 24$ hours, central venous pressure 9 cmH2O. Hb 9,9 g/dL; WBC $15.890 / \mathrm{mm}^{3}$; neutrophil $83 \%$, Platelets $324.000 / \mathrm{mm}^{3}$; GDA $93 \mathrm{mg} / \mathrm{dL}$; AST 58 IU/L; ALT $19 \mathrm{IU} / \mathrm{L}$; direct bilirubin $4.3 \mathrm{mg} / \mathrm{dL}$; total bilirubin $6.8 \mathrm{mg} / \mathrm{dL}$; BUN $49 \mathrm{mg} / \mathrm{dL}$; SK $3.2 \mathrm{mg} / \mathrm{dL}$; $\mathrm{Na} 133 \mathrm{mEq} / \mathrm{L} ; \mathrm{K} 3,6 \mathrm{mEq} / \mathrm{L} ; \mathrm{Cl} 94 \mathrm{mEq} / \mathrm{L}$. The patient was assessed with AKI with polyuria phase, and was administered intravenous fluid of normal saline 1000 $\mathrm{mls}$ in three hours, proceeded by $1000 \mathrm{mls}$ of D5, 500 $\mathrm{mls}$ of normal saline, and $500 \mathrm{mls}$ of kalbamin in 24 hours. Oral fluid intake $1500 \mathrm{mls}$ per 24 hours.

In the seventeenth day of treatment, the patient had no complaints. Vital signs are adequate, jaundice clinically improved, urine output $3000 \mathrm{mls}$ per 24 hours, and drainage production $400 \mathrm{mls}$ per 24 hours. $\mathrm{Hb} 9,9 \mathrm{~g} / \mathrm{dL}$; WBC $11.620 / \mathrm{mm}^{3}$; Neutrophil 72\%; platelets $301.000 / \mathrm{mm}^{3}$, BUN $35 \mathrm{mg} / \mathrm{dL}$; SK $1.8 \mathrm{mg} / \mathrm{dL}$ The patient was discharged and scheduled for internal medicine polyclinics visit.

\section{DISCUSSION}

The patient arrived in the emergency room with the chief complaint of fever 2 weeks before admission. We found tachycardia, hyperthermia, hypercapnia, and leukocytosis, which matches the criteria of systemic inflammatory response syndrome (SIRS) by Society of Critical Care Medicine (SCCM), which consists of fever of more than $38^{\circ} \mathrm{C}\left(100.4^{\circ} \mathrm{F}\right)$ or less than $36^{\circ} \mathrm{C}$ $\left(96.8^{\circ} \mathrm{F}\right)$, heart rate of more than 90 beats per minute, respiratory rate of more than 20 breaths per minute or arterial carbon dioxide tension $(\mathrm{PaCO} 2)$ of less than 32 $\mathrm{mm} \mathrm{Hg}$, and abnormal white blood cell count $(>12,000 /$ $\mu \mathrm{L}$ or $<4,000 / \mu \mathrm{L}$ or $>10 \%$ immature forms). ${ }^{4,5}$ The patient also had positive blood culture and matching bile culture, therefore meeting the criteria of sepsis, which adds the presence of confirmed or presumed infection on top of SIRS criteria. Furthermore the patient also meets severe sepsis criteria, which adds organ dysfunction, hypoperfusion, or hypotension ${ }^{5}$, evidenced with AKI and hyperbilirubinemia in this case.

Over the years, the definition and management of sepsis underwent several changes. The Sepsis-3 task force, convened in 2014 by the SCCM and the European Society of Intensive Care Medicine (ESICM), introduced new definitions for sepsis and septic shock based on advances in the scientific understanding of this complex syndrome. . $^{6,7}$ A principal change in the new definitions was the requirement that sepsis be triggered by infection. This pathobiological understanding removes SIRS from the definition of sepsis, as numerous conditions other than infection may cause SIRS. The Sepsis-3 definitions focus on the understanding that sepsis is a multifaceted patient response to infection and results in organ dysfunction. ${ }^{6,8}$ The new definitions thus focus on organ dysfunction and hypoperfusion in the presence of infection, rather than on inflammation (specifically SIRS). Sepsis is a lifethreatening organ dysfunction caused by a dysregulated patient response to infection. In lay terms, sepsis is a life-threatening condition that arises when the body's response to infection causes injury to itself and its organs. Furthermore, the term severe sepsis is no longer recommended, as it is hard to identify clinically and is not helpful in guiding clinical treatment interventions Septic shock is now defined as a subset of sepsis in which the patient has profound hypoperfusion, and is seen in patients with sepsis who develop underlying circulatory and metabolic abnormalities resulting in hypotension that require vasopressors to maintain a MAP of $\geq 65$ $\mathrm{mmHg}$ and having a serum lactate level of $\geq 2 \mathrm{mmol} / \mathrm{L}$ 
despite adequate volume resuscitation, resulting in a higher risk of mortality. ${ }^{6,8}$ The emphasis in the Sepsis-3 definitions on organ dysfunction caused by infection requires clinicians to take a more concentrated, objective approach to the assessment of organ function. The Sepsis-3 recommendation is to use an organ dysfunction assessment tool to identify patients with sepsis. ${ }^{9}$

The sequential organ failure assessment (SOFA), most commonly used in ICUs, is effective in quantifying the severity of organ dysfunction and morbidity and estimating mortality risk. It evaluates the following physiologic functions: respiration, coagulation, hepatic, cardiovascular, central nervous system, and renal. In order to calculate a patient's SOFA score, it is necessary to obtain the following laboratory values: bilirubin, creatinine, coagulation studies, and arterial blood gases. ${ }^{10}$ However, while these can reveal organ dysfunction, they may not accurately reflect the patient's perfusion status. The higher the SOFA score, the greater the patient's risk of morbidity and mortality. ${ }^{11}$ The scoring system of SOFA can be seen in Table 1.

The score is evaluated in each system, and the score of 2 or more in any system indicates increased risk of organ dysfunction, poor outcome, or death. The scores are then accumulated, and the overall score is used to predict mortality in the intensive care unit (ICU) (Table 2). ${ }^{10}$

This patient received score of 1 for respiration, 0 for coagulation, 4 for liver function, 1 for cardiovascular, 0 for central nervous system, and 4 for renal function, which yielded the total score of 10 . Therefore, there is a risk of renal and liver failure in this patient, with mortality rate of $40-50 \%$ if the patient is admitted to the ICU. The results of this assessment, in addition to the patient's history and clinical presentation, support the rapid implementation of fluid resuscitation, rapid antibiotic administration, frequent reassessment, and targeted organ support to prevent further clinical deterioration.
Table 2. Overall SOFA score and the risk of mortality in the ICU

\begin{tabular}{ll}
\hline Maximum SOFA score & Mortality \\
\hline 0 to 6 & $<10 \%$ \\
7 to 9 & $15-20 \%$ \\
10 to 12 & $40-50 \%$ \\
13 to 14 & $50-60 \%$ \\
15 & $>80 \%$ \\
15 to 24 & $>90 \%$ \\
\hline SOFA : sequential organ failure assessment, ICU: intensive care with unit
\end{tabular}

The quick SOFA (qSOFA), an abbreviated organ dysfunction assessment, was introduced in Sepsis-3. The qSOFA relies on only three variables: systolic blood pressure, respiratory rate, and mentation. In nonICU patients, the qSOFA score predicts elevated risk of death and extended ICU stay, but it is not designed to stand alone as an early warning of sepsis or to identify which patients should be transferred to the ICU. ${ }^{12}$

Regarding the etiology of from which the infection occured, it was most likely from the underlying disease in this patient, which is cholangiocarcinoma, assumed to be associated with hepatitis B, which required percutaneous transhepatic biliary drainage to redirect the bile fluid due to obstruction. The malignancy in this patient pays major contribution to his immunodeficiency. Earlier evidence has determined that bile becomes contaminated and cholangitis may occur after PTBD. However, there have been no reports describing the timing of the onset of bacteribilia and cholangitis after PTBD. Cholangitis and biliary sepsis are inevitable complications which can occur despite adequate antibiotic coverage. Although exact etiology is unknown, it can occur due to multitude of factors such as retrograde reflux of intestinal flora during the procedure, ex vitro infection tracking along the drainage catheter, or may be of hematogenous origin. ${ }^{13}$

Bacterial translocation has a prevalence of about $15 \%$ in elective surgical patients and occurs more frequently in patients with intestinal obstruction and those who are immunocompromised. There are various

Table 1. Sequential organ failure assessment (SOFA) scoring system ${ }^{10}$

\begin{tabular}{|c|c|c|c|c|c|}
\hline System & 0 & 1 & 2 & 3 & 4 \\
\hline $\begin{array}{l}\text { Respiration } \\
\mathrm{PaO} 2 / \mathrm{FIO} 2 \mathrm{~mm} \mathrm{Hg}\end{array}$ & $\begin{array}{l}\geq 400 \\
(53.3)\end{array}$ & $\begin{array}{l}<400 \\
(53.3)\end{array}$ & $\begin{array}{l}<300 \\
(40)\end{array}$ & $\begin{array}{l}<200(26.7) \\
\text { with respiratory support }\end{array}$ & $\begin{array}{l}<100(13.3) \\
\text { with respiratory support }\end{array}$ \\
\hline $\begin{array}{l}\text { Coagulation } \\
\text { Platelets } \times 10^{3} / \mathrm{uL}\end{array}$ & $\geq 150$ & $<150$ & $<100$ & $<50$ & $<20$ \\
\hline $\begin{array}{l}\text { Liver } \\
\text { Bilirubin mg/dL (umol/L) }\end{array}$ & $\begin{array}{l}<1.2 \\
(20)\end{array}$ & $\begin{array}{l}1.2-1.9 \\
(20-32)\end{array}$ & $\begin{array}{l}2.0-5.9 \\
(33-101)\end{array}$ & $\begin{array}{l}6.0-11.9 \\
(102-204)\end{array}$ & $\begin{array}{l}>12.0 \\
(204)\end{array}$ \\
\hline Cardiovascular & $\begin{array}{l}\text { MAP } \\
\geq 70 \mathrm{mmHg}\end{array}$ & $\begin{array}{l}\text { MAP } \\
<70 \mathrm{mmHg}\end{array}$ & $\begin{array}{l}\text { Dopamine }<5 \text { or } \\
\text { Dobutamine (any dose) }\end{array}$ & $\begin{array}{l}\text { Dopamine } 5.1-15 \text { or } \\
\text { Epinephrine } \leq 0.1 \text { or } \\
\text { Norepinephrine } \leq 0.1\end{array}$ & $\begin{array}{l}\text { Dopamine }>15 \text { or } \\
\text { Epinephrine }>0.1 \text { or } \\
\text { Norepinephrine }>0.1\end{array}$ \\
\hline CNS GCS Score & 15 & $13-14$ & $10-12$ & $6-9$ & $<6$ \\
\hline $\begin{array}{l}\text { Renal creatinine, } \mathrm{mg} / \mathrm{dL} \\
\text { (umol/L) } \\
\text { Urine Output, mL/d }\end{array}$ & $<1.2(110)$ & $\begin{array}{l}1.2-1.9 \\
(110-170)\end{array}$ & $\begin{array}{l}2.0-3.4 \\
(171-299)\end{array}$ & $\begin{array}{l}1.5-4.9 \\
(300-440) \\
<500\end{array}$ & $\begin{array}{l}>5.0(440) \\
<200\end{array}$ \\
\hline
\end{tabular}


factors that contributes to bacterial translocation, such as the impaired defense of host mucosal barrier and permeability due to physical breaches following ulceration; disruption of gastrointestinal microflora, which often occurs in critical illness; and impaired immune status, which diminishes the phagocytosis of translocating bacteria before reaching mesenteric lymph nodes or lymphatic vessel, thus permitting egress and survival of these bacteria at distant extra-intestinal sites. Jaundice also have been shown to influence translocation, particularly in animals. ${ }^{14}$

When classifying the sterility of interventional procedures, bile duct drainages will be categorized as "clean/contaminated procedure" in up to $30 \%$ of cases of malignant obstructions and $60 \%$ of benign obstructions. In the latter instance, the risk of infectious complication can be as high as $40 \%$. Transient bacteremia occurs in approximately $2 \%$ of patients after biliary intervention. In addition, many patients attending for this procedure have advanced malignancy and may have established sepsis prior to operating. The complication rate, including infection is lower in patients with benign disease. The mortality rate for biliary drainage is approximately $2 \%$, sepsis and hemorrhage being the two leading causes of death. ${ }^{15}$

The precipitation of sepsis is felt to be due to mechanical agitation of an infected biliary system causing bacteremia. In addition, the passage of a needle through the liver has the potential to provide temporary communication between the biliary system and the surrounding vasculature, allowing a passage of bacteria from the infected bile into the blood. The use of ultrasound guidance

rather than fluoroscopic guidance to obtain biliary access, can reduce the number of passes required through the liver. This could in turn result in less agitation of bile and fewer infective complications. Risk factors for developing sepsis include biliaryenteric anastomosis and previous instrumentation. Risk factors for contamination of the bile prior to intervention include older age, diabetes, acute cholecystitis and previous biliary surgery. Clearly many patients presenting for PTC will fall into at least one of these demographic groups. ${ }^{15}$

In cases of fatal biliary sepsis of any kind, the most common causative organisms are E. coli and clostridium, which account for $75 \%$ of cases, although one group found that enterococcus is the most likely organism to be cultured from the blood post biliary intervention. Other organisms commonly isolated from the biliary tree include Klebsiella, Enterobacter cloacae, Streptococcus viridans, and various yeasts. ${ }^{15}$

Because of the high rate of infectious complications the routine use of prophylactic antibiotics is advocated. Even in patients with theoretically adequate antibiotic coverage, organisms can often be cultured from blood samples post biliary drainage. This may be due to inadequate choice or timing of antibiotics or because of a large bacterial load following manipulation. There is little agreement in the literature regarding the most appropriate coverage for biliary procedures; however, the high rate of biliary excretion of third generation cephalosporins means they are ideal for use as an antibiotic prophylaxis in biliary procedures. Alternatively ampicillin/sulbactam can be given, this having a greater activity against enterococcus spp. In the absence of sepsis, antibiotic cover should continue until the system is fully drained ${ }^{15}$.

In the dr. Soetomo General Hospital's 2017 data of microbial patterns, Eschericia coli can be found in $22.3 \%$ blood culture in all wards (second-most after Klebsiella pneumoniae), and for sterile fluid culture, E. coli can be found in $20.1 \%$ samples in all wards (second most after Pseudomonas aeruginosa). ${ }^{16}$

Table 3. Distribution of isolated microbes from culture specimens in Dr. Soetomo General Hospital in 2017

\begin{tabular}{lll}
\hline All wards & Blood culture & $\begin{array}{l}\text { Sterile fluid } \\
\text { culture }\end{array}$ \\
\hline Klebsiella pneumoniae & $193(23.2 \%)$ & $21(11.4 \%)$ \\
Eschericia coli (all wards) & $185(22.3 \%)$ & $37(20.1 \%)$ \\
Eschericia coli (surgery wards) & - & $25(100 \%)$ \\
Acinetobacter baumanii & $113(13.6 \%)$ & $35(19.0 \%)$ \\
Enterobacter cloacae & $52(6.2 \%)$ & $9(4.8 \%)$ \\
Pseudomonas aeruginosa & $50(6.0 \%)$ & $39(21.2 \%)$ \\
\hline
\end{tabular}

Nosocomial bacteremias were defined as those with first culture-positivity $\$ 48$ h following hospital admission or within $48 \mathrm{~h}$ of discharge. Communityonset infections were defined as those with first culture-positivity within $<48 \mathrm{~h}$ of admission or $>$ $48 \mathrm{~h}$ after discharge from hospital. A healthcareassociated community-onset $E$. coli bacteremia was in addition associated with at least one of the following: (i) discharge from an adult home parenteral therapy clinic within 2-30 days before bloodstream infection; (ii) attendance at a hospital clinic or emergency room within 2-30 days before bloodstream infection; (iii) admission to a CHR acute- care hospital for two or more days within the 90 days before bloodstream infection; (iv) sample submission from a patient who previously sent a sample from a nursing home or a long-term-care facility; and (v) outpatient hemodialysis. ${ }^{17}$ While there 
is always a possibility of hospital acquired infection, it is unlikely to occur in this case, due to administration of prophylactic antibiotics before, during, and after the procedure.

The patient also suffered acute kidney injury (AKI), which is a common complication in critically ill patients and is associated with increased morbidity and mortality. Although the functional consequences during sepsis-induced AKI are dramatic, the histological changes are moderate and do not entirely explain the clinical phenotype. Recent evidence suggests that instead of a single mechanism being responsible for its etiology, sepsis is associated with an entire orchestra of cellular mechanisms, adaptive and maladaptive, which potentiate each other and ultimately give rise to clinical AKI. The microcirculation is perhaps the more important physiological compartment where these mechanisms come together and exert their integrated and deleterious action. These mechanisms include endothelial dysfunction, inflammation, coagulation disturbance, and adaptive cell responses to injury. ${ }^{18}$ Therefore, we hypothesize that a key event in the early dysfunction of the kidney during sepsis is a bio-energetic stress of the tubular epithelial cells, in response to the amplified inflammatory signal that peritubular microvascular dysfunction generates. ${ }^{19}$

Sepsis and septic shock are regarded as medical emergencies. Therefore, early effective fluid resuscitation is crucial for the stabilization of sepsisinduced tissue hypoperfusion or septic shock. Given the urgent nature of this medical emergency, initial fluid resuscitation should begin immediately upon recognizing a patient with sepsis and/or hypotension and elevated lactate, and completed within 3 hours of recognition. The guidelines recommend this should comprise a minimum of $30 \mathrm{~mL} / \mathrm{kg}$ of intravenous crystalloid fluid. Although little literature includes controlled data to support this volume, recent interventional studies have described this as usual practice in the early stages of resuscitation, and observational evidence is supportive ${ }^{20}$ The absence of any clear benefit following the administration of colloid compared with crystalloid solutions in the combined subgroups of sepsis, in conjunction with the expense of albumin, supports a strong recommendation for the use of crystalloid solutions in the initial resuscitation of patients with sepsis and septic shock. Because some evidence indicates that a sustained positive fluid balance during ICU stay is harmful, fluid administration beyond initial resuscitation requires careful assessment of the likelihood that the patient remains fluid responsive. This patient received 1500 $\mathrm{ml}$ of crystalloid fluid in three hours for initial fluid resuscitation. ${ }^{21}$

Urgent restoration of an adequate perfusion pressure to the vital organs is a key part of resuscitation. This should not be delayed. If blood pressure is not restored after initial fluid resuscitation, then vasopressors should be commenced within the first hour to achieve mean arterial pressure (MAP) of $\geq 65 \mathrm{~mm} \mathrm{Hg}$. The physiologic effects of vasopressors and combined inotrope/vasopressor selection in septic shock are outlined in a large number of literature reviews. ${ }^{22}$ The use of CVP alone to guide fluid resuscitation can no longer be justified because the ability to predict a response to a fluid challenge when the CVP is within a relatively normal range $(8-12 \mathrm{~mm} \mathrm{Hg})$ is limited. The same holds true for other static measurements of right or left heart pressures or volumes. Dynamic measures of assessing whether a patient requires additional fluid have been proposed in an effort to improve fluid management and have demonstrated better diagnostic accuracy at predicting those patients who are likely to respond to a fluid challenge by increasing stroke volume. This patient has achieved MAP of $\geq 65 \mathrm{~mm}$ $\mathrm{Hg}$ after initial fluid resuscitation, so vasopressors were not necessary.

Sterilization of cultures can occur within minutes of the first dose of an appropriate antimicrobial ${ }^{23}$, so cultures must be obtained before antibiotic administration to optimize the identification of pathogens and improve outcomes. ${ }^{24}$ Appropriate blood cultures include at least two sets (aerobic and anaerobic). Administration of appropriate antibiotic therapy should not be delayed in order to obtain blood cultures. In this patient, blood culture was obtained before the first dose of empiric antibiotics administration.

Empiric broad-spectrum therapy with one or more intravenous antimicrobials to cover all likely pathogens should be started immediately for patients presenting with sepsis or septic shock. ${ }^{25}$ Empiric antimicrobial therapy should be narrowed once pathogen identification and sensitivities are established, or discontinued if a decision is made that the patient does not have infection. The link between early administration of antibiotics for suspected infection and antibiotic stewardship remains an essential aspect of high-quality sepsis management. If infection is subsequently proven not to exist, then antimicrobials should be discontinued. This patient received a combination of levofloxacin and ceftazidime before 
the blood and bile culture results were identified, after which the blood and bile culture results was identified and the antibiotics were switched to meropenem, which the pathogen is sensitive against.

Regarding the treatment of renal complications of sepsis, it is suggested that either continuous RRT (CRRT) or intermittent RRT be used in patients with sepsis and acute kidney injury (weak recommendation, moderate quality of evidence), although it is not recommended in patients with sepsis and acute kidney injury for increase in creatinine or oliguria without other definitive indications for dialysis. ${ }^{26}$ This patient experienced oliguria In this patient, hemodialysis was indicated by refractory hyperkalemia.

We have reported a cholangiocarcinoma patient with sepsis related to PTBD procedure. Eschericia coli was found in bile and blood culture. He also had AKI as a complication. The patient's SOFA score is 4 for renal function and liver function. He received dual antimicrobial therapy until the blood and bile culture came out, after which the antimicrobial therapy was switched accordingly. Fluid rescuscitation must be given as soon as possible, for restoration ofan adequate perfusion pressure to the vital organs was a key part of resuscitation. Antimicrobial therapy according to microbial sensitivity test was given to this patient. If there is any indication, renal replacement therapy can be used.

\section{REFERENCES}

1. Finfer S, Machado FR. The global epidemiology of sepsis. Does it matter that we know so little? Am J Respir Crit Care Med 2016;193:228-30.

2. Xie J, Robertson J, Chen CW, Zhang W, Coopersmith $\mathrm{CM}$, Ford M. Pre-existing malignancy results in increased prevalence of distinct populations of CD4+ T cells during sepsis. Plos One 2018;13:1-20.

3. Torres V, Azevedo L, Silva U, Caruso P, Torelly A, Silva E, et al. Sepsis-associated outcomes in critically ill patients with malignancies. Ann Am Thorac Soc 2015;12:1185-92.

4. Levy MM, Fink MP, Marshall JC, Abraham E, Angus D, Cook $\mathrm{D}$, et al. $2001 \mathrm{SCCM} / \mathrm{ESICM} / \mathrm{ACCP} / \mathrm{ATS} / \mathrm{SIS}$ International Sepsis Definitions Conference. Crit Care Med 2003;31:1250-6.

5. Bone RC, Balk RA, Cerra FB, Dellinger RP, Fein AM, Knaus WA, et al. Definitions for sepsis and organ failure and guidelines for the use of innovative therapies in sepsis. The $\mathrm{ACCP} / \mathrm{SCCM}$ Consensus Conference Committee. American College of Chest Physicians/Society of Critical Care Medicine. Chest 1992;101:1644-55.

6. Seymour CW, Liu VX, Iwashyna TJ, Brunkhorst FM, Rea TD, Scherag A, et al Assessment of clinical criteria for sepsis: for the third international consensus definitions for sepsis and septic shock (Sepsis-3). JAMA 2016;315:762-74.

7. Hari MS, Philips GS, Levy ML, Seymour CW, Liu VX, Deutschman C, et al. Developing a new definition and assessing new clinical criteria for septic shock: for the third international consensus definitions for sepsis and septic shock (Sepsis-3). JAMA 2016;315:775-87.

8. Singer M, Deutschman C, Seymour CW. The third international consensus definitions for sepsis and septic shock (Sepsis-3). JAMA 2016;315:801-10.

9. Makic MBF \& Bridges E. Managing sepsis and septic shock: current guidelines and definitions. Am J Nurs 2018;118:34-9.

10. Jones AE, Trzeciak S, Kline JA. The Sequential organ failure assessment score for predicting outcome in patients with severe sepsis and evidence of hypoperfusion at the time of emergency department presentation. Crit Care Med 2009;37:1649-54.

11. Raith EP, et al. Prognostic accuracy of the SOFA score, SIRS criteria, and qSOFA score for in-hospital mortality among adults with suspected infection admitted to the intensive care unit. JAMA 2017;317:290-300

12. Donnelly JP, Safford MM, Shapiro NI, Baddley JW, Wang HE, et al. Application of the third international consensus definitions for sepsis (Sepsis-3) classification: a retrospective populationbased cohort study. Lancet Infect Dis 2017;17:661-70.

13. Chandrashekhara SH, Gamanagatti S, Singh A, Bhatnagar S Current status of percutaneous transhepatic biliary drainage in palliation of malignant obstructive jaundice: a review. Indian J Palliat Care 2016;22:378-87.

14. MacFie J. Current status of bacterial translocation as a cause of surgical sepsis. British Medical Bulletin 2004;71:1-11.

15. Halpenny DF, Torreggiani WC. The infectious complications of interventional radiology based procedures in gastroenterology and hepatology. J Gastrointest Liver Dis 2011;20:71-5.

16. Adiwinoto RP, Sustini F, Hardiono H, Widodo AD, Hidajat B, Hadi U. Empirical antibiotic therapy assessment of patients diagnosed with sepsis in intermediate care ward of internal medicine department of Dr. Soetomo General Hospital according to Gyssens method. Oceana Biomedicina Journal 2018;1:69-78.

17. Laupland KB, Gregson DB, Church DL, Ross T, and Pitout JDD, 2008. Incidence, risk factors and outcomes of Escherichia coli bloodstream infections in a large Canadian region. Clinical Microbiology \& Infections 2008;14:1041-47.

18. Le Dorze M, Legrand M, Payen D, and Ince C. The role of the microcirculation in acute kidney injury. Current Opinion in Critical Care 2009; 15:503-8.

19. Zarbock A, Gomez H, and Kellum JA. Sepsis-induced AKI revisited: pathophysiology, prevention and future therapies. Current Opinion in Critical Care 2014;20:588-95.

20. Levy MM, Rhodes A, Phillips GS, Townsend SR, Schorr CA, Beale R, et al. Surviving sepsis campaign: association between performance metrics and outcomes in a 7.5-year study. Crit Care Med 2015; 43:3-12.

21. Brotfain E, Koyfman L, Toledano R, Borer A, Fucs L, Ori Galante, et al. Positive fluid balance as a major predictor of clinical outcome of patients with sepsis/septic shock after ICU discharge. Am J Emerg Med 2016;34:2122-6.

22. Zhou SX, Qiu HB, Huang YZ, Yang Y, Zheng RQ. Effects of norepinephrine, epinephrine, and norepinephrine-dobutamine on systemic and gastric mucosal oxygenation in septic shock. Acta Pharmacol Sin 2002;23:654-8.

23. Zadroga R, Williams DN, Gottschall R, Hanson K, Vickie Nordberg, Marcia Deike, et al. Comparison of 2 blood culture media shows significant differences in bacterial recovery for patients on antimicrobial therapy. Clin Infect Dis 2013;56:790-7. 
24. Cardoso T, Carneiro AH, Ribeiro O, Teixeira-Pinto A, Costa-Pereira A. Reducing mortality in severe sepsis with the implementation of a core 6-hour bundle: results from the Portuguese community- acquired sepsis study (SACiUCI study). Crit Care 2010;14:R83.

25. Kumar A. Systematic bias in meta-analyses of time to antimicrobial in sepsis studies. Crit Care Med 2016;44:e234 e235.

26. Rhodes A, Evans LE, Alhazzani W, Levy MM, Antonelli M, et al. Surviving Sepsis Campaign: International Guidelines for Management of Sepsis and Septic Shock: 2016. Crit Care Med 2017;45:1-67. 